\title{
Treatment with vacuum-assisted closure system: A case of anastomotic leak after upper gastrointestinal surgery
}

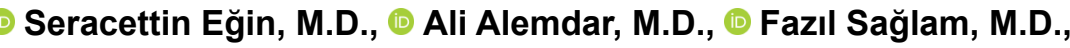 \\ 다 Burak Güney, M.D., 다 Hakan Güven, M.D.
}

Department of General Surgery, University of Health Sciences, Okmeydanı Training and Research Hospital, İstanbul-Turkey

\begin{abstract}
Presently described is a case treated via stent and vacuum-assisted closure (VAC). The patient developed an oesophagojejunostomy leak $(\mathrm{OL})$ on the ninth postoperative day after a radical total gastrectomy. The patient was a 55-year-old male patient with adenocarcinoma localized to the small curvature on the corpus of the stomach. Relaparatomy was performed for the OL, including placement of an uncovered stent. The abdomen was washed 4 times. As the OL did not decrease, 2 covered stents $(22 \mathrm{~mm}$ and $18 \mathrm{~mm}$ in diameter and $80 \mathrm{~mm}$ long) were inserted endoscopically. The OL continued to contaminate the abdomen. One tip of the VAC sponge was placed next to the anastomosis, and the other tip was removed from the left upper quadrant. Another VAC closure set was placed in the abdomen. Both VAC closures were connected to separate vacuum devices with $75 \mathrm{mmHg}$ of pressure.VAC dressings were changed at regular intervals every 3 days, and these steps were repeated 7 times over 21 days. The covered stents were removed endoscopically in the final operation. Fistulography revealed that the OL was completely closed, and the VAC dressings were removed. The skin was closed by separating the subcutaneous oil layer of the fascia.VAC therapy can not only provide serious abdominal sepsis treatment and primary source control, but also accelerate granulation development and, in this case, quickly closed the anastomotic leakage.
\end{abstract}

Keywords: Anastomotic leak; oesophageal stent; open abdomen; vacuum assisted closure.

\section{INTRODUCTION}

Anastomotic leak (AL) after upper gastrointestinal system surgery is life-threatening. Endoscopically applied oesophageal stents and percutaneous drainage via radiological imaging are conventional minimally invasive strategies for the treatment of $A L$. When a leak is stented and treatment with minimally invasive methods, such as percutaneous drainage, is attempted, a continuing leak can become the primary origin of abdominal sepsis. Minimally invasive treatment modalities are sometimes not sufficient for source control and sepsis management, and therefore there can be a high mortality rate in these patients. Although the popularity and frequency of use of the Bogota bag have decreased, this procedure is still used in a staged laparotomy after intra-abdominal irrigation and passive drainage. This application can increase the inci- dence of enteroatmospheric fistula, as well as damage to the fascia and skin. Sometimes, abdominal irrigation in repeated laparotomies is used to try to control intra-abdominal sepsis. Mortality and morbidity increase with repeated operations. Moreover, the length of hospital stay is extended.

Presently described is a case in which, within a short time, the open abdomen (OA) technique with vacuum-assisted closure (VAC) was implemented in addition to oesophageal stent applications for an oesophagojejunostomy leak originating from open radical total gastrectomy and D2 lymph node dissection.

\section{CASE REPORT}

An open radical total gastrectomy was performed for a

Cite this article as: Eğin S, Alemdar A, Sağlam F, Güney B, Güven H. Treatment with vacuum-assisted closure system: A case of anastomotic leak after upper gastrointestinal surgery. Ulus Travma Acil Cerrahi Derg 2018;24:601-603.

Address for correspondence: Seracettin Eğin, M.D.

Sağılık Bilimleri Üniversitesi, Okmeydanı Eğitim ve Araştırma Hastanesi, Genel Cerrahi Kliniği, İstanbul, Turkey

Tel: +90 212 - 3145555 E-mail: seracettin_egin@hotmail.com

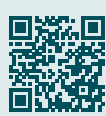

Ulus Travma Acil Cerrahi Derg 2018;24(6):60I-603 DOI: 10.5505/tjtes.2018.23238 Submitted: 10.08.2017 Accepted: 15.10.2018 Online: 01.11 .2018

Copyright 2018 Turkish Association of Trauma and Emergency Surgery 
55-year-old male patient on October 24, 2016. AL was verified with computerized tomography on October 30, 2016, and the case was observed conservatively until the postoperative ninth day. Relaparotomy was performed on the postoperative ninth day. Endoscopy was performed during the operation and a 5-mm patency was seen on the blind small intestine side of the oesophagojejunostomy line. An uncovered stent passed through the anastomosis line was positioned. The inside of the abdomen was cleaned with saline and the skin was closed. The procedure was performed twice more on the postoperative $10^{\text {th }}$ and $13^{\text {th }}$ days. On the postoperative $14^{\text {th }}$ day, a fluoroscopic examination was performed using contrast. An AL was identified in the abdomen (Fig. Ia). On the postoperative $15^{\text {th }}$ day, 2 covered stents, $22 \mathrm{~mm}$ and 18 $\mathrm{mm}$ in diameter, were inserted within the earlier stent. On the postoperative $17^{\text {th }}$ day, a VAC management system was applied (ABThera Open Abdomen Management System; Kinetic Concepts Inc./Acelity, L.P. Inc., San Antonio, TX, USA). One of the additional sponge extensions was extracted from the management system. One tip of the extracted additional sponge extension was placed next to the anastomosis under the left diaphragm and the other tip was taken out of the left upper quadrant. Five additional sponge extensions were carried out the intra-abdominal cavity. Both were separately connected to 2 vacuum devices with $75 \mathrm{mmHg}$ pressure. The external appearance after the first VAC application can be seen in Figure Ib. VAC procedures were carried out with a 3-day interval, taking a liquid culture from the abdomen and washing the abdomen. The second VAC procedure is shown in Figure Ic. The suppurative collection in the left subdiaphragmatic cavity is illustrated in Figure Id. It was observed during the fluoroscopic examination performed on the postoperative $29^{\text {th }}$ day that the AL persisted (Fig. Ie). On the postoperative $34^{\text {th }}$ day, the covered stents were removed, but the uncovered stent could not be extracted. A fluoroscopic examination was performed on the postoperative $36^{\text {th }}$ day and the AL was not present (Fig. If). The seventh and last VAC procedure was performed on the postoperative $37^{\text {th }}$ day. No collection in the left subdiaphragmatic cavity was observed during this procedure (Fig. Ig). The VAC dressing was removed on the postoperative $4 \mathrm{I}^{\text {st }}$ day. The subcutaneous layer was then dissected from the fascial layer of the anterior wall of the abdomen (Fig. Ih). The abdominal skin was closed without tension (Fig. Ii). The entire clinical course of the case is summarized in the illustration (Fig. I). The patient was discharged on the postoperative $58^{\text {th }}$ day.

\section{DISCUSSION}

The two-way VAC technique was added to the treatment plan when the intra-abdominal contamination and sepsis parameters did not resolve despite the application of oesophageal stents and planned re-laparotomies, in order to control the primary source. This technique can localize the peritoneal contamination by creating a separate tract for the AL. Thus, peritoneal contamination can be limited to a narrow region under the diaphragm, and the AL will not infect the intraabdominal cavity. In addition, VAC quickly improves granulation and completely closes the leak in a short amount of time. This patient was our first case using this strategy after an AL following upper gastrointestinal system surgery. To the best of our knowledge, there is no other case like ours in the literature.

Most leaks are minor and can be managed conservatively with nasogastric suction, local drainage, antibiotics, and jejunal feeding. If there is continuing or worsening sepsis, an early operation may be necessary for a good outcome. Recently, endoscopic interventions, such as esophageal stenting, have
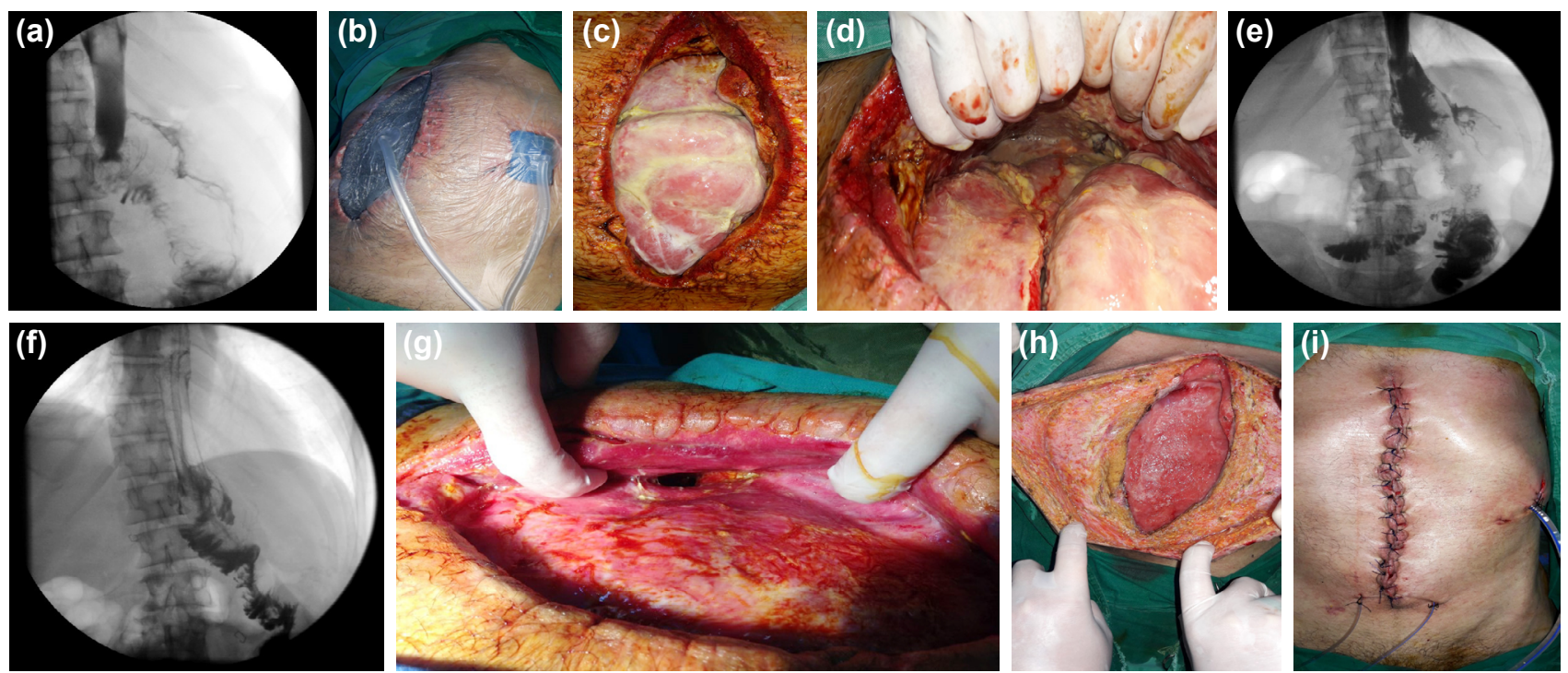

Figure 1. (a) The leak was identified from oesophagojejunostomy. (b) The external appearance of the final state of VAC. (c) The appearance of the intestine during second VAC. (d) Collection in the left subdiaphragmatic cavity. (e) Anastomosis leak on the postoperative $29^{\text {th }}$ day. (f) No contrast leak on the postoperative $36^{\text {th }}$ day. (g) No collection in the left subdiaphragmatic cavity. (h) The subcutaneous layer dissected from the fascia. (i) The abdomen was closed with skin layer. VAC: Vacuum-assisted closure. 
been successfully used for the management of $A L .^{\left[{ }^{[l]}\right.}$ But these interventions may not always be sufficient for primary source control and abdominal sepsis management.

The high mortality rate is usually due to sepsis and the comorbidities of patients undergoing relaparotomy. A conservative approach should always be considered as the treatment of choice, as most leaks are minor and only demonstrated radiologically. ${ }^{[2]}$ Reoperation may be necessary in cases of wide dehiscence or when other treatments fail. Major leakage from the oesophagojejunal anastomosis following total gastrectomy for gastric malignancy usually occurs early (within 72 hours of surgery) and mediastinitis is often fatal. Surgical re-exploration is warranted: either dismantling the anastomosis and performing a primary repair if feasible (but which is often futile), or the creation of a controlled fistula, and in all cases, performing washout, drainage, and insertion of feeding jejunostomy. ${ }^{[3,4]}$ The best results can be achieved in leaks occurring after the very early postoperative phase with a covered self-expanding stent. ${ }^{[5]}$ In delayed leaks, the decision is radiological drainage or surgical re-exploration. ${ }^{[3]}$

Abdominal sepsis is the host's systemic inflammatory response to bacterial or yeast peritonitis. ${ }^{\left[{ }^{[6]}\right.}$ Severe sepsis is defined as sepsis associated with organ dysfunction or tissue hypoperfusion. ${ }^{[7]}$ The OA technique may be an important option in the surgical management of severe peritonitis. ${ }^{[8]}$ In OA, VAC techniques have used extensively as a method to achieve temporary abdominal wall closure.

In conclusion, VAC therapy not only provides serious abdominal sepsis treatment and primary source control, but also accelerates granulation development and closes the $A L$ in a short period of time.
Conflict of interest: None declared.

\section{REFERENCES}

1. Schaheen L, Blackmon SH, Nason KS. Optimal approach to the management of intrathoracic esophageal leak following esophagectomy: a systematic review. Am J Surg 2014;208:536-43. [CrossRef]

2. Sano T, Sasako M, Yamamoto S, Nashimoto A, Kurita A, Hiratsuka $\mathrm{M}$, et al. Gastric cancer surgery: morbidity and mortality results from a prospective randomized controlled trial comparing D2 and extended para-aortic lymphadenectomy-Japan Clinical Oncology Group study 9501. J Clin Oncol 2004;22:2767-73. [CrossRef]

3. Aurello P, Magistri P, D’Angelo F, Valabrega S, Sirimarco D, Tierno SM, et al. Treatment of esophagojejunal anastomosis leakage: a systematic review from the last two decades. Am Surg 2015;81:450-3.

4. Etoh T, Inomata M, Shiraishi N, Kitano S. Revisional surgery after gastrectomy for gastric cancer: review of the literature. Surg Laparosc Endosc Percutan Tech 2010;20:332-7. [CrossRef]

5. Hoeppner J, Kulemann B, Seifert G, Marjanovic G, Fischer A, Hopt UT, et al. Covered self-expanding stent treatment for anastomotic leakage: outcomes in esophagogastric and esophagojejunal anastomoses. Surg Endosc 2014;28:1703-11. [CrossRef]

6. Sartelli M, Catena F, Di Saverio S, Ansaloni L, Malangoni M, Moore EE, et al. Current concept of abdominal sepsis: WSES position paper. World J Emerg Surg 2014;9:22. [CrossRef]

7. Dellinger RP, Levy MM, Carlet JM, Bion J, Parker MM, Jaeschke R, Reinhart K, et al; International Surviving Sepsis Campaign Guidelines Committee; American Association of Critical-Care Nurses; American College of Chest Physicians; American College of Emergency Physicians; Canadian Critical Care Society; European Society of Clinical Microbiology and Infectious Diseases; et al. Surviving Sepsis Campaign: international guidelines for management of severe sepsis and septic shock: 2008. Crit Care Med 2008;36:296-327. [CrossRef]

8. Schein M. Surgical management of intra-abdominal infection: is there any evidence? Langenbecks Arch Surg 2002;387:1-7. [CrossRef]

\section{OLGU SUNUMU - ÖZET}

\section{Vakum yardımlı kapama sistemi ile tedavi: Üst gastrointestinal cerrahiden sonra anastomoz kaçağı olan bir olgu}

\section{Dr. Seracettin Eğin, Dr. Ali Alemdar, Dr. Fazıl Sağlam, Dr. Burak Güney, Dr. Hakan Güven}

Sağlık Bilimleri Üniversitesi, Okmeydanı Eğitim ve Araştırma Hastanesi, Genel Cerrahi Kliniği, İstanbul

Radikal total gastrektomi sonrası ameliyat sonrası dokuzuncu günde ozofagojejunostomiden kaçak nedeniyle stent ve vakum yardımlı kapatma uyguladığımız olguyu sunmayı amaçladık. Mide korpus küçük kurvatüründe adenokarsinom olan 55 yaşındaki erkek hastaya radikal total gastrektomi yapıldı. Ameliyat sonrası dokuzuncu günde anastomoz kaçağı saptanması nedeniyle, kapsız stent yerleştirilmesini de içeren relaparatomi yapıldı. Daha sonra karın dört defa yıkandı. Kaçak azalmadığından 22 ve $18 \mathrm{~mm}$ çapında $80 \mathrm{~mm}$ uzunluğundaki 2 kaplı stent içiçe endoskopik olarak yerleştirildi. Kaçak batını kirletmeye devam etti. Beşinci defa batın yıkama esnasında vakum yardımlı kapama (VAC) sistemi ile tedavi yönetimine karar verildi. VAC süngerinin bir ucu anastomozun yanına yerleştirildi ve diğer ucu sol üst kadrandan çıkarıldı. Batın içine başka bir VAC kapama seti yerleştirildi. Her iki VAC, $75 \mathrm{mmHg}$ basınç ile iki ayrı vakum cihazına bağlandı. VAC değişiklikleri her üç günde bir düzenli aralıklarla 2 I gün içinde yedi defa tekrarlandı. Kaplı stentler son operasyonda endoskopik olarak çıkarıldı. Ameliyat sonrası 36. gündeki fistülografide kaçağın tamamen kapandığını görüldü ve VAC sistemi çıkarıldı. Cilt, fascia üzerindeki subkütan yağ tabakasını ayırarak kapatıldı. VAC sistemlerinin uygulanması, ciddi batın içi sepsis tedavisi ve birincil kaynak kontrolü sağlamakla kalmaz aynı zamanda granülasyon gelişimini hızlandıır ve anastomoz kaçağııı daha kısa zaman içinde kapatır

Anahtar sözcükler: Açık karın; anastomoz kaçağı; özofagus stenti; vakum yardımlı kapama.

Ulus Travma Acil Cerrahi Derg 2018;24(6):601-603 doi: 10.5505/tjtes.2018.23238 